\title{
A small scale project that involved citizens in the education of social work students during their placement in Northern Ireland
}

\section{Paul McCafferty}

Summary: This article outlines my attempt to create a small scale project, with the aim of involving citizens in the education of student social workers whilst on their placement in Northern Ireland. The article outlines the literature on the subject, describes how the project evolved and discusses how citizens were involved in the direct teaching process. The article continues by describing how the teaching input of the citizens was then transferred into educating five students. The article evaluates the educational impact on the students and discusses the value of involving citizens in the education process during placement. This project was part of my dissertation for my Joint Advanced MSc in Social Work, presented to The University of Ulster and Queens University Belfast.

Keywords: placement; citizen

1. Principal Social Worker, Training, Western Health and Social Care Trust

Address for Correspondence: Riverview House, Abercorn Rd., Derry. BT48. paul.mccafferty@westerntrust.hscni.net

Date of publication: 25th June 2010

Acknowledgement: I would like to thank the three citizens who gave their time to the project. I would also like to thank the two managers who committed to the project so readily.

115 J. of Practice Teaching \& Learning 9(2) 2009, pp.115-138. DOI: 10.1921/146066910X518139. ( $w \& b$ 


\section{Introduction}

The call for citizen involvement has been a feature of good social work practice ever since the writers of the Seebohm Report pointed towards the restructuring of social services which took place in the 1970s. The terms of engagement altered over the following years, and by the 1980s and 1990s, citizen involvement had become a major preoccupation and empowerment was the new buzz word. The reasons for this vary but can be linked initially to the disenchantment with the British Welfare State (Pithouse \& Williamson, 1997). Simultaneously, new assertive organisations and movements of people who used services emerged, ranging from young people in care to people with mental distress (Beresford \& Croft, 1993). They rejected the poor quality, paternalism and social control of welfare services. As a result new kinds of services appeared providing a participatory framework for a variety of groups.

Additionally, the Conservative government agenda in the 1980s of cost efficiency, control and competition produced a situation where in place of experts deciding consumer needs 'the needs and demands of consumers determine the content and organisation of services' (Kirkpatrick \& Lucio, 1995, p.29). Running in tandem with these developments were policy and legislative requirements for more citizen involvement in child protection, physical and learning disability, mental health, further education and housing (Abrams, 1984).

The question raised by these developments is no longer whether people should have a voice in services but how this is to be achieved. 'It is not just the promise of greater citizen involvement that's now needed, but ways of realising it. It's time to move from rhetoric to reality' (Beresford \& Croft, 1993, p.44).

\section{Rationale for the project}

The rationale for this project was to respond to the changing policy, political and practical demands for citizen involvement by creating a project that would involve citizens in the education of social work students whilst on their placement. Where citizens are involved, services are more inclusive, streamlined, efficient and effective at meeting needs (Hodge, 2005). It is hoped that involving citizens in

116 J. of Practice Teaching \& Learning 9(2) 2009, pp.115-138. DOI: 10.1921/146066910X518139. @ wEb 
the direct teaching of students on their placement will enhance their educational experience and ultimately improve services to citizens themselves. As Rojek et al. (1988) argue the most neglected resources in the current systems are the ideas and experiences of citizens. Additionally, as Tyler (2006) argues, students who are taught from the outset that citizens are an integral part of the education process soon accept citizen involvement as critical to their development, more readily than their peers who have not had the same experiences. Finally, I hope this project will begin to forge a new dynamic relationship between the worlds of citizens and social work educators. At present these two worlds are still too far apart and collide on a tokenistic level. I hope that by developing this project that the two worlds will become more closely aligned with one another for the mutual benefit of both.

\section{Literature search}

\section{Definitions}

To begin with, I feel it is critical to look at the important issue of definition. In line with Duffy (2006) I shall use the term citizen as opposed to service user. Duffy offers a good rationale for this, arguing that the term service user implies the passive receipt of a service echoing Levin (2007) who argues that the term is potentially disempowering. Beresford and Croft (2004) argue that the term citizen implies citizenship which is a status bestowed on those who are full and equal members of a community, a notion first introduced by Marshall in 1950. This notion of equality is also reflected by BASW (1981), Thompson (2000), and Adams, et al. (2002), stating that citizenship is an important social work value, promoting right, social inclusion and having the right to be included in mainstream society.

\section{The policy content}

Citizen participation is an idea supported by policy and legislation on a national level. Duffy (2008) offers a useful time line (see appendix 1) of key policy and legislation initiatives that have helped cement the notion

117 J. of Practice Teaching \& Learning 9(2) 2009, pp.115-138. DOI: 10.1921/146066910X518139. @ wE-b 
that citizens need to be involved in health and social care service planning and delivery. What is clear from examining Duffy's time line is that the concept of citizen involvement is absolutely embedded in the psychic of policy makers in the UK. With specific reference to policy directives in relation to social work education in Northern Ireland where this project is located, one can see a raft of explicit references in a wide variety of Northern Ireland Social Care Council documents relating to the Degree in Social Work (NISCC, 2003, 2004, 2005, 2006, 2007) making it incumbent on course and placement providers to involve citizens in the planning, delivery and evaluation of courses and placements.

\section{What the literature has to say}

It was not until the last 30 or 40 years that citizens have been systematically involved in the education of social work students. Edwards (2004) and Croft and Beresford (1997) identify the starting point as the work of Mayer and Timms (1970). Edwards also identifies developmental studies in this area such as Brandon and Davies (1979), Wikler (1979), Furniss (1988), Baird (1990), Shardlow and Doel (1993), Croft and Beresford (1997), Shenan (1998), Fisher (1983), and Phillips (1983), all of whom state that involving citizens in the education of students has an overwhelmingly positive effect on the students.

Work by Rees and Wallace (1982) and Evans (1997) examine the rationale for involving citizens in the education of students and conclude that citizen involvement enhances practice assessment but warn that difficulties can exist in relation to citizens giving accurate and meaningful feedback. Problems identified include elucidating honest and objective feedback, compliance, indiscriminate praise, unrepresentative negative feedback and making judgments about whether the citizen is commenting on the inadequacies of the service or the student abilities (Rees \& Wallace, 1982). However, as Leiper and Fidd (1993) and Hennessy (1999) argue these difficulties can be overcome so long as practice teachers plan the feedback carefully.

Shenan (1998) quoting legislative demands for citizen involvement (Children Act, 1989; NHS and Community Care Act, 1990) and the growing concerns about social workers competence in the light of several major child abuse enquires began to look at the training social work students received. In particular, he questioned the adequacy of

118 J. of Practice Teaching \& Learning 9(2) 2009, pp.115-138. DOI: 10.1921/146066910X518139. @ wE-b 
the assessment of student's competence arguing that one method of ensuring the assessment of students is more detailed, accurate and helpful, would be to involve citizens in the process. Shenan supports his argument for greater citizen involvement in the assessment of students by outlining the findings of Wikler (1979), Renon and Sayce (1993), Fisher (1983), Cheetam et al. (1992), MacDonald et al. (1992), Baird (1990), Doel and Shardlow (1991), and Furness and Ross, 1993, who all argue convincingly for the need to involve citizens in the assessment of student social workers.

Forbes and Sashidharan (1997), however, warn against seeing citizen involvement as straightforward and transparently helpful. These writers identify, along with Collins and Stein (1989), and Croft and Beresford, (1992,) the conceptual confusion that characterises much of the debate, since participation can mean anything from manipulation to citizen control, including non-participation, varying degrees of tokenism or degrees of power' (Forbes and Sashidharan, 1997, p.482). They also point to the level of attention given to the theoretical and political background of citizen involvement. Generally they argue the terms of citizen involvement and the value base attached to it have not been fully discussed.

Despite this Beresford (2000) building on the work of (Curran, 1997; Lukes, 1974; Foucault, 1975, and Gould, 1994) argues that the knowledge of citizens should be incorporated into the theorising elements of social work. Beresford argued that, because citizens' knowledge is based on direct experience of policy, practice and services, it is cutting edge and relevant. However, Beresford (2002, p.493) warns that there is a tendency for these inputs to be 'devalued in dominant professional discourses as grey literature'. This appears to reflect the concerns of two citizens, Rimmer and Harwood (2004) who developed a citizen involvement project for the degree in social work. They state that there were huge barriers to their participation on the degree but that once made, their contributions were an invaluable source of knowledge, skill and value development for the facilitators and students alike. This study is interesting on another level however. Would Rimmer and Harwood have encountered the same barriers if they had been classed as lecturers in the employ of the University and perceived as academic experts in their own right? It raises the spectre of what constitutes true engagement, full participation and valuing the input of citizens as being equal to that of perceived academic experts. 
It also raises the issue of language and definitions. What do we call citizens who have an input to education? Are they citizens who can contribute something to teaching or are they lecturers who enjoy the same status, pay and benefits as their academic colleagues? When they give lectures are their lectures given the same weight and recognition as their academic colleagues or is this still classed as grey literature? It appears obvious that until citizens are given the same status as their academic colleagues then their contribution may still be classed as something of less value than their academic equivalents.

Writing in (2005) Hodge develops this theme applauding the attempts to involve citizens in the planning and delivery of services. However, she cites the work of Barnes and Prior (1995), Barnes and Shardlow (1996, 1997), Boul (1996), Beresford (2001), and Croft and Beresford $(1992,1995)$ as evidence that the involvement of citizens can be limited, tokenistic, problematical and minimalist. Waterson and Morris (2005) argue however that if citizens are involved properly, especially in the educational context from the beginning then the experience can be wholly positive.

These findings are supported by Ager et al. (2005) who established a Grassroots Network of citizens who became involved in social work teaching at Dundee University. They incorporated Arnstein's Ladder of Participation adapted by Mackay (2002) to plot the level of participation achieved and found that through the establishment of a network of citizens, carers and those involved in social work education that people were able to share knowledge and ideas using network processes. They conclude that incorporating the community based expertise of citizens and carers was a helpful approach to expanding the knowledge, skills and values of the students.

In tandem with this progress there has been a dual development with regards to citizen involvement in education and their general political activity and lobbying expertise (Duffy, 2006). These developments which began in the 1970s have now found formal expression in the New Honours Degree in Social Work introduced in September 2003. Duffy (2004) argues that the modernisation of social work training in the United Kingdom began with the Government's Quality Strategy for Social Care (2000), which placed an emphasis on providing high quality social work services. In addition, the Requirements for Social Work Training, issued by the Department of Health (2002) also specifically sets out the roles of seven key groups in the design and delivery of social work

120 J. of Practice Teaching \& Learning 9(2) 2009, pp.115-138. DOI: 10.1921/146066910X518139. @ wEb 
programmes. In the latter, citizens are distinctly assigned with having roles in all parts of social work programme design and delivery from student selection to quality assurance. NISCC, established in 2001, also states, in its Rules for the Approval of the Degree in Social Work (2003), that citizens must be involved in all aspects of design and delivery of social work education.

Additionally, the National Occupational Standards also include a Statement of Expectations from those who use services and carers, referred to in the Northern Ireland Framework Specification (2003, p.35). Levin (2004, p.9) sees this as enabling students to see 'citizens as active participants in service-delivery rather than passive recipients'. In 2004, the General Social Care Council (GSCC) analysed how these developments and recommendations were being put into practice in universities in the UK. The GSCC reported that citizen involvement in the degree was starting to make a real impact but the rate of progress was better in some places compared with others. With regards to developments in the Northern Ireland context it appears that government, employers and professionals now share a commitment to promoting citizen involvement in all aspects of planning, delivery, and monitoring of health and social services. It is further hoped that the new Northern Ireland Assembly will provide even more impetus and resources essential to securing the mainstreaming and further development of citizen involvement within all health and social services organisations. This is especially important given that the literature on citizen involvement whilst recognising many difficulties and barriers, nearly always points to the overall benefits of involving citizens.

\section{The project}

To begin the project, I recruited two managers from a placement provider called Partnership Care West (PCW) to form the project team. PCW is the provider to which I was attached as an independent practice teacher at the time of the project. Our first task was to write a comprehensive statement of ethics which would act as an objective measurement of everything we did as a team during the life of the project. This statement would be a standard item on every agenda and every action of the team would be measured against this statement.

121 J. of Practice Teaching \& Learning 9(2) 2009, pp.115-138. DOI: 10.1921/146066910X518139. @ wEbb 
We then needed to recruit citizens willing to take part in the project. To do this we put flyers around the entire organisation asking for volunteers and at the same time the managers asked citizens they worked with if they would be interested. In this way it was hoped we would have a mixture of citizens that the project team knew (convenience sample) and those whom the team did not know directly (random sample). This echoes the recommendations of Beresford and Croft (1993) and Beresford (2000) who argue that it is important that every effort is made to engage with more marginalised groups. Unfortunately, despite the best efforts of the team we were unable to reach the random sample and had to go with our convenience sample of three. Despite not reaching the random sample we still felt the project had merit and that we should continue with the convenience sample. I do, however, recognise that the hardest to reach and most marginalised groups are sometimes the ones we can learn from the most. We discussed this contradiction and whether or not we should discontinue the project. After careful consideration however and having weighed up the advantages and disadvantages we decided to continue. We felt that continuing with the convenience sample was still worthwhile as it represented the beginning of an organic process that would hopefully lead one day to full representation of all citizens.

The next issue we dealt with involved writing an information letter to citizens who had volunteered. When this letter was drafted I presented it to one of the sample who stated he didn't want to read it and that he couldn't understand it. I discussed my experience with the team and we hypothesised that perhaps the letter was much too long (one thousand words), was too jargonistic and therefore possibly intimidating. We also measured the letter against our statement of ethics and felt that the letter did not meet the objective standards we had set ourselves. This was oppressive and it was agreed to issue citizens with an amended information flyer instead which was less jargonised.

The next task was to decide upon a strategy for involving the citizens in the teaching process. After much discussion, it was agreed that the best way of managing the process and protecting the citizens, would be to develop a set of standardised questions. A team member would then show these to the citizens for prior approval. When approval had been given we would then video tape an interview with the citizen being asked the questions by one of the managers that the citizen already worked with. During the taping of the session the citizens would also

122 J. of Practice Teaching \& Learning 9(2) 2009, pp.115-138. DOI: 10.1921/146066910X518139. @ wEb 
have their back to the camera to protect their confidentiality. These tapes would then be played back to the students in controlled seminar fashion. This method of involvement is in line with Waterson and Morris (2005) who argue that one of the best ways to involve citizens in a teaching input is to video their contribution and then play this to students. To this end the team drew up a set of protocols for the citizen which gave them control of the session and a set of protocols for the interviewer to ensure the sessions were conducted in a manner consistent with the ethical statement.

It was agreed the questions would be general in orientation and that no personal information would be sought. It was also agreed that the citizen could chose not to answer any question without explanation and that the tape could be stopped at any time. The interview would be semi structured but there would be a self imposed limit to the level of probing which should be in accordance with the ethical statement. The following questions formed the basis for the interview.

1. What was it like to have a social worker?

2. Were there any benefits to having a social worker?

3. Did you feel fully involved in all decisions?

4. Would you recommend having a social worker?

5. Did you understand the role of your social worker?

6. Can you give two suggestions that would help improve the practice of a social worker?

The next stage was to show the videos to the students in a seminar. The entire point of showing the videos in this way was that it was the citizens doing the teaching via their video taped narrative. The learning came from reflecting, analysing and discussing the themes arising from the narratives and transferring this learning into the practice. The students watched each video three times and took notes as they watched. We then discussed the issues they identified and grouped them into the emerging themes.

\section{Themes emerging from Interview/Video No 1}

The citizen is a young homeless person recently discharged from residential care. The citizen is now in temporary accommodation.

123 J. of Practice Teaching \& Learning 9(2) 2009, pp.115-138. DOI: 10.1921/146066910X518139. @ wEbb 
- The young person 'felt involved in the decisions that were made' and that the social worker gave her information.

- However, this was not done consistently. Sometimes the young person was 'not consulted about decisions that were taken at case conferences'. This caused her anger and resentment.

- 'Meetings were generally arranged at suitable times'. However, the young person stated that when she really needed her social worker e.g. at night if she was feeling depressed, the social worker was not available.

- Young person could not say what the benefits of having a social worker were

- Stated social worker was 'generally helpful but not always'.

\section{Themes emerging from Interview/Video No 2}

Citizen is a 19 year old male who had a social worker since he was born. He said the following:

- He had 'no say in decisions when he was younger'.

- Social workers 'did not have skills to understand him'.

- Social workers 'did not listen to him'.

- He had 'never seen his file, despite asking for it'.

- He was not 'involved in planning his future'.

- Felt he 'was out on his own at 16 years'.

- He didn't 'really understand the role of his social worker'.

- He felt social workers were interfering, 'they do your head-in'.

\section{Themes emerging from Interview/Video No 3}

This citizen was a young single mother with three children who were on the Child Protection Register at one point. She stated the following:

- Social worker 'was excellent support'.

- They helped 'children get into other clubs'.

- 'Helped me when I was down'.

- Would recommend to anyone having a social worker.

- She understood role, and was 'involved in all decisions'.

124 J. of Practice Teaching \& Learning 9(2) 2009, pp.115-138. DOI: 10.1921/146066910X518139. @ wEb 
- She was listened to.

- Social workers shouldn't judge 'not everyone is the same'.

Once the videos had been viewed the students discussed the learning they gained as a result of listening to the citizens narratives. Again these are outlined in themes.

Learning from interviews/videos that could be transferred into practice

- That as a student one should always explain their role with clarity.

- That as social workers we must ensure we involve citizens as much as possible in decisions about their lives.

- That formal meetings should be more citizen friendly.

- That meetings should be arranged at times that suit citizens, even if this is after $5 \mathrm{pm}$.

- Give young people a say in their care; even if they are very young. It is up to social workers to develop the skills to communicate effectively with children and young people, not the other way around.

- That the skill of listening well is the one skill valued by citizens above all others.

- Ensure citizens have regular access to their files. Regularly remind citizens that they are entitled to see their files. Make this process less intimidating.

- When young people reach the age of between 16 and 18 years, they should not be left to 'go it alone'.

- That in time of need, social workers are a very real help.

- That social workers can access different supports for citizens.

- Social workers must try hard not to judge people.

- That values are exceptionally important in social work.

- That partnership, empowerment and anti-oppressive practice are not lofty ideals but when enacted, make a real difference to people.

At the end of the seminar, and in line with suggestions from Rae (2002), I evaluated the seminar in group discussion format. In terms of the evaluation the students all agreed 'that the session was really powerful', 'that it really makes you think' and 'for me the whole antioppressive issue was really strong'. Additionally the students commented that 'the video really told it like it is' 'some of that was overwhelming' and 'It's just so important to work in partnership'. Issues that students will put into practice included 'I will work harder at understanding life 
from the citizens point of view', 'I need to work harder at partnership during assessments', 'I have to develop better listening skills', 'you have to stick with citizens through thick and thin' and 'it makes the care cycle clearer and how important it is to follow that properly'.

Now that the seminar had finished, it was important to acknowledge the input of the citizens with a thank you letter. This is in line with the opinions of Bowl (1996), Barnes and Shardlow (1996), Barnes and Prior (1995), Beresford (2000), Croft and Beresford (1997), and Wright et al. (2005) who argue that if citizens are involved in any way in the education process that their contribution must be seen as being equal to that of professionals and given the same amount of recognition.

\section{Lessons learned from the project}

\section{Planning}

There are many lessons learned as a result of conducting this project but I have outlined the main ones here. The first lesson I have learned from involving citizens in the education of students is the importance of careful and meticulous planning. At the beginning stage it was important to get all the protocols developed, the ethical considerations finalised, the publication literature made crystal clear, and all other working standards, agreements and policy and procedures finalised. This was vitally important because the entire essence of the project involved working with vulnerable people and I wanted the work to be of the highest ethical and professional standards possible. This requirement for exacting these high standards when involving citizens echoes the works of (Stevenson and Parsloe, 1993; Jordan, 1990; Croft and Beresford, 1997,1993 and Edwards, 2004) who argue that systems for involving citizens must have a high ethical content, must take into consideration the needs of citizens and must have professional integrity.

\section{Team approach}

The second lesson learned was the use of a team approach. The use of the team meant that all the protocols, agreements and working

126 J. of Practice Teaching \& Learning 9(2) 2009, pp.115-138. DOI: 10.1921/146066910X518139. @ wEb 
standards reached their peak as a result of debate, refinement, synthesis, consultation and challenge.

\section{Citizen involvement}

Our third lesson was that we should have involved a representative from the citizen population as part of the project team from the very beginning. We could have canvassed for volunteers to take part as team members before we canvassed for actual volunteers for the project. This would have ensured that citizens were involved in drawing up the protocols, ethical statement, and questions for interview. In relation to the seminar we could have supported the citizens to design and deliver the seminar themselves and to facilitate the student's learning. This would require meticulous planning, support and training for the citizen's but it is an approach which resonates with Hodge (2005), Reynolds and Reed (1999), Barnes et al. (2000), Barnes and Shardlow (1996, 1997), Doel (1996), and Beresford (2001), who argue that citizens should be involved centrally in planning, delivering and evaluating services.

\section{Representation}

The fourth lesson was about representativeness which is discussed by Hasler (2003). We wanted volunteers from as wide a source as possible to ensure we included hard to reach individuals. Getting as many people involved would avoid tokenism and getting the best citizens who were the most able, articulate, empowered and capable of entering a more formal system. This is also in line with what Shenan (1998) (Renon and Jayce (1993), Baird (1990), Forbes and Sashidharan (1997), Croft and Beresford (1992, 1997, 2000), and Rimmer and Harwood (2004) state when they stress the importance of involving as wide a range of citizens as possible and who argue that barriers to participation must be addressed to ensure inclusion, citizenship and participation. This issue was discussed and we redoubled our efforts to try and engage as wide a range of volunteers as possible but to no avail. This was disappointing but we all agreed we had done everything we could to recruit widely and that we would have to run with our convenience sample rather than

127 J. of Practice Teaching \& Learning 9(2) 2009, pp.115-138. DOI: 10.1921/146066910X518139. @ w\&b 
give up on the project. I feel the issue of representativeness remains a real challenge for social workers and is something that will require much further work. If we agree as Brendan and Davis (1979), Wickler (1979), Furniss (1998), Baird (1990), Shardlow and Doel (1993), Croft and Beresford (1997), Edwards (2003, and Chatham et al. (1992) encourage us to that involving citizens in social work education must be an essential ingredient in the academic career of social work students and that it has universally positive results, then we must try harder as a profession to reach these citizen groups.

\section{Learning}

The fifth lesson learned also supports this argument which was about the learning that we receive as social workers from citizens. The analysis of the project taken from the students at the end of the seminar was overwhelmingly positive. This pays testimony to the importance of using this medium in the educational lives of students. These positive findings are also reflected by Edwards, 2004; Croft and Beresford, 1997; Mayer and Timms, 1970; Brandon and Davies, 1979; Wikler, 1979; Furness, 1988; Baird, 1990; Shardlow and Doel, 1993; and Shenan 1998) who state that involving citizens in practice learning has overwhelmingly positive outcomes in a variety of areas associated with practice learning. Findings further supported by (Renon and Jayce, 1993; Fisher, 1989; Cheetham et al., 1992; and McDonald et al., 1992) who state that when citizens' views are incorporated into the design, delivery and evaluation of services, that these services are better suited to meeting the needs of the public. It is therefore clear that educationalists must give this medium of teaching much more thought in future.

\section{Conclusion}

When I read the literature on citizen involvement, I agreed that citizens and practitioners should meet together as fellow citizens to reason about ethical dilemmas, practice issues, assessment, educational issues, service planning and delivery, (Seebohm Report, 1968; Barclay Report, 1982) and that they should be involved in a truly empowering way

128 J. of Practice Teaching \& Learning 9(2) 2009, pp.115-138. DOI: 10.1921/146066910X518139. @ wE-b 
(Stevenson and Parsloe, 1993; Jordan, 1990). I strongly believed that it was possible to work in true partnership (Dalrymple and Burke, 2001), and that citizens should be empowered to participate (Dubois and Krogsrud Miley, 1992). I also believed as Rojek et al. (1998) state that citizens are our most neglected resource in planning and delivering care.

This is why I undertook this project to begin to foster the conditions whereby citizen involvement in social work education can begin to be seen as essential, central and mainstream. Whilst this was a small project, the findings from the student evaluations lend credence to the notion that involving citizens in student education during the placement has a genuinely positive impact on their knowledge, skill and value development. Personally speaking, this was a deeply gratifying project to be involved in. I feel very privileged to have been associated with the citizens and was exceptionally grateful for their full involvement. The citizens were very forthright in their views and I feel we all benefited from their involvement. The learning gained as a result of their input was very deep, lasting and meaningful; more so than lots of more traditional approaches to teaching that I have used in the past. Due to the level of learning gained, I feel this type of project could and should be expanded, developed and made more mainstream. I feel that we are professionally responsible to adapt and be more responsive to the changing regulatory, social, political and professional demands on us as educators. Involving citizens in this process appears to me to make good sense judging by the positive impact it has had on students.

\section{References}

Abrams, P. (1984) Reality of Neighborhood Care, Policy and Politics, 12, 4, 413-29 Adams, R. (1990) Self-help, Social Work and Empowerment, Schooling and the State, Basingstoke, Falmer

Adams, R. Dominelli, L. and Payne, M. (2002) Critical Practice in Social Work Palgrave, Basingstoke

Ager, W. Dow, J. and Gee, M. (2001) Grassroots Networks: A Model for Promoting the Influence of Service Users and Carers, Social Work Education, 10, 24-30

Arstein, S. (1969) A Ladder of Citizen Participation, Journal of the American Institute of Planners Vol 35, 446244 cited in Duffy, J. (2006) Citizen Involvement in Social work in Northern Ireland Context SCIE

129 J. of Practice Teaching \& Learning 9(2) 2009, pp.115-138. DOI: 10.1921/146066910X518139. @ wEbb 
Audit Commission (1986) Making a Reality of Community Care, London HMSO

Baird, P. (1990) The Proof of the Pudding: a Study of Clients Views of Student Competence, Issues in Social Work Education 10, 1, 24-50

Banks, S. (2001) Ethics and Values in Social Work (2nd Ed) BASW, Palgrave

Barclay Report (1982) Social Workers: Their Role and Tasks, London, Bedford Square Press

Barnes, D. Carpenter, J. and Bailey, D. (2000) Partnerships with Service Users in Interprofessional Education for Community Mental Health: A Case Study, Journal of Interprofessional Care, 14, 2, 189-200

Barnes, M. and Prior, D. (1995)'Spoilt for Choice? How Consumerism can Disempower Public Services' Public Money and Management, July-Sept 53-8 Cited in Hodge, S. (2005) Participation, Discourse and Power, A Case Study in Citizen Involvement, Critical Social Policy 25, 164-179

Barnes, M. and Shardlow, P. (1996) Effective Consumers and Active Citizens: Strategies for Users Influence on Service and Beyond, Research Policy and Planning 14, 1, 33-8 Cited in Hodge, S. (2005) Participation, Discourse and Power, A Case Study in Citizen Involvement, Critical Social Policy 25 164-179 BASW (1981) Clients as Fellow Citizens. Birmingham: BASW

Beresford, P. (2000) Citizens' Knowledge and Social Work Theory: Conflict or Collaboration, British Journal of Social Work, 30, 489-503

Beresford, P. and Croft, S. (1993) Citizen Involvement, A Practical Guide for Change, Macmillan Press Ltd

Beresford, P. Page, L. and Steven, A. (1994) Changing the Culture: Involving Service Users in Social Work Education, CCETSW Paper 32.2 London: Central Council for Education and Training in Social Work,

Bowl, R. (1996) 'Legislation for User Involvement in the United Kingdom: Mental Health Services and the NHS and Community Care Act 1990, International Journal of Social Psychiatry 42, 3, 165-180 cited in Duffy, J. (2006) Citizen Involvement in Social work in Northern Ireland Context SCIE

Brandon, J. and Davies, M. (1979) The Limits of Competence in Social Work: The Assessment of Marginal Students in Social Work Education, British Journal of Social Work 9, 3, 295-348

Cairncross, L. Clapham, D. and Goodland, R. (1993) Bases of Tenant Organisations, Housing Studies, 8, 179-193 cited in Pithouse, A. and Williamson, H. (1997) Engaging the User in Welfare Services, Venture Press

Central Housing Advisory Committee (1969) Council Housing: Purposes, Procedures and Priorities, London HMSO

Central Housing Advisory Committee (1959) Councils and their Homes, London HMSO cited in Pithouse, A. and Williamson, H. (1997) Engaging the User in

130 J. of Practice Teaching \& Learning 9(2) 2009, pp.115-138. DOI: 10.1921/146066910X518139. @ wEb 
Citizens in the education of social work students on placement in Northern Ireland

Welfare Services, Venture Press

Cheetham, J. Fuller, K. McIvor, G. and Petch, A. (1992) Evaluating Social Work Effectiveness, Buckingham, Open University Press

Collins, S. and Stein, M. (1989)'Users fight Back': Collectives in Social Work, London Routledge

Committee of Vice-Chancellors and Principals (1991) Audit Notes of Guidance, Paper 91/1001, London CVCP

Croft, S. and Beresford, P. (1997) Service Users' Perspectives London

Dalrymple, J. and Burke, B. (2001) Anti-Oppressive Practice: Social Care and the Law, Open University Press, Buckingham, Philadelphia

Department of Health (1989) Caring for People, Community Care in the Next Decade and Beyond, London, HMSO

Department of Health (1989a) Working for Patients, London HMSO

Department of Health (1989b) Caring for People: Community Care in the Decade and Beyond, London HMSO

Department of Health (1992) The Patients Charter, London, HMSO

Department of Health (2000) A Quality Strategy for Social Care, London: DH

Department of Health (2000) The NHS Plan, Department of Health, London

Department of Health (2002) Requirements for Social Work Training, London: DH

Department of Health (July 2000) Better Care Higher Standard

Department of Health and Social Services (1975) Better Services for the Mentally Ill, London, HMSO

Department of the Environment (1977) Housing Policy: A Consultative Document, London HMSO

Department of the Environment (1987) Housing The Governments Proposals, CMND 214, London HMSO

DH (1992) Local Voices, London DH

DH (1997) The NHS: Modern, Dependable, London DH

DH (2000) The NHS Plan: A Plan for Investment, A Plan for Reform, London DH

DH (2003) Building on the Best Choice: Responsiveness and Equity in the NHS, London DH

DH (2003b) Department of Health Priorities Framework 2003-2006, London: DH

DH (2006a) Our health, Our Care, Our Say, London: The Stationary Office

DH (2006b) National Health Service Act (England), London: The Stationary Office

DH (Department of Health) (1991) The Patients Charter, London DH

DHSS (1997) The Regional Strategy for Health and Social Well-being 1997-2002, as cited in SSI (1997) Consumer involvement changing attitudes, Belfast: DHSS

DHSSPSNI (2002) Valuing Carers: A Strategy for Carers in Northern Ireland, Belfast: DHSSPSNI

131 J. of Practice Teaching \& Learning 9(2) 2009, pp.115-138. DOI: 10.1921/146066910X518139. @ wEbb 
DHSSPSNI (2003) Health and Personal Social Services (Regulation and Quality Improvement) NI Order 2003, London: The Stationery Office

DHSSPSNI (2004) Equality and Inequalities in Health and Social Care: A statistical Overview, Belfast

DHSSPSNI (2004) A Healthier Future 2005-2025, Belfast: DHSSPSNI

DHSSPSNI (2006) Reward and Recognition: The principles and Practice of Service User Payment and Reimbursement in Health and Social Care. A Guide for Service Providers, Service Users and Carers, Belfast: DHSSPSNI

DHSSPSNI (2006b) The Quality Standards for Health and Social Care, Belfast: DHSSPSNI

DHSSPSNI (Department of Health, Social Services and Public Safety Northern Ireland) (2001) Best Practice, Best Care DHSSPSNI(2007a) Draft Framework for Stakeholder Involvement in Health and Social Care, November, Belfast: DHSSPSNI

DHSSPSNI(2007) Health and Social Services (Reform) (NI) Draft Order, Belfast: DHSSPSNI

DHSSPSNI(2007) The Priorities for Action 2007-2008, Belfast: DHSSPSNI

DHSSPS (2003) Northern Ireland Framework Specification for the Degree in Social Work

DHSSPSNI (2004) Equality and Inequalities in Health and Social Care: A Statistical Overview, Belfast

Doel, M. and Shardlow, S. (1991) The Practice Portfolio: Examining Student Practice University of Sheffield Department of Sociological Studies

Du Bois, B. and Krogsrud, Miley, K. (1992) Social Work, An Empowering Profession, Allyn and Boston

Duffy, J. (2008) Looking out from the Middle: User Involvement in Health and Social Care in Northern Ireland, SCIE Stakeholder Participation Report 18

Duffy, J (2006) Citizen Involvement in Social Work Education in the Northern Ireland Context: A Good Practice Guide, SCIE

Edwards, C. (2003) The Involvement of Service Users in the Assessment of Diploma in Social Work Students on Practice Placements, Social Work Education, 22, 4

Evans, D. (1997) Demonstrating Competence in Social Work, cited in Davies, M. (ed) The Blackwell Companion to Social Work (Oxford, Blackwell)

Fisher, M. (1983) The Future of Client Studies, in Fisher, M. (ed) Speaking of Clients, Chapter 4, University of Sheffield, Joint Unit for Social Sciences Research.

Forbes, J. and Sashidharan, SP. (1997) User Involvement in Services - Incorporation or Challenge, British Journal of Social Work, 27, 481-498

Forrest, S. Risk, I. Masters, H. and Brown, N. (2000) Mental Health Service User Involvement in Nurse Education: Journal of Psychiatric and Mental Health Nursing, 7, 51-57

Furness, J. (1988) The Client Speaks Again, Profile, 3 p2-3

132 J. of Practice Teaching \& Learning 9(2) 2009, pp.115-138. DOI: 10.1921/146066910X518139. @ wEb 
Citizens in the education of social work students on placement in Northern Ireland

General Social Care Council (2004) Working Towards full Participation - A Report on how Social Work Degree Courses, which Started in 2003 have begun to Involve Citizens and Carers in Social Work Education

Hodge, S. (2005) Participation, Discourse and Power: A case study in Citizen Involvement, Critical Social Policy, 25, 164-179

Hasler, F. (2003) Users at the Heart: User Participation in the Governance and Operations of Social Care

Jordan, B. (1990) Social Work in an Unjust Society, Hemel Hempstead; Harvester Press

Kerman. L, Treseder, P. and Connor, J. (2004) Children are Citizens Too, London, Save the Children

Khoo, R. McVicar, A. and Brandon, D. (2004) Citizen Involvement in Postgraduate Education. Does it Benefit Practice? Mental Health Education, 13, 5, 481-492

Kirby, P, Lanyon. C. Cronin, K. and Sinclair, R. (2003) Building a Culture of Participation, London

Kirkpatrick, I. and Lucio, M. (1995)(eds) The Politics of Quality, London, Routledge cited in Pithouse, A. and Williamson, H. (1997) Engaging the Citizen in Welfare Services, Venture Press

Klatt, B. (1999) The Ultimate Training Workshop Handbook, McGraw-Hill

Lansdowne, G. (2001) Promoting Children's Participation in Democratic Decision Making, London UNICEF

Leiper, R. and Field, V. (1993) Counting for Something in Mental Health Services Aldershot Avebury

Levin, E. (2004) Involving Service Users and Carers in Social Work Education SCIE The Policy Press, Bristol

Lodge, P. (1997) Users in Higher Education, Venture Press

Mackay, K. (2002) From Consultation to Participation: A study of Users/Survivors as Co-producers of Mental Health Services, Msc Dissertation, University of Stirling, cited in Ager, et al. (2000)

Marshal, T.H. (1950) Citizenship and Social Class, London, Cambridge University Press

Mayer, J. and Timms, N. (1970) The Client Speaks, London, Routledge and Keegan Paul

McDonald, G. and Sheldon, B. with Gillespie, J (1992) Contemporary Studies of the Effectiveness of Social Work effectiveness, British Journal of Social Work, $22,5,615-643$

McNeish, D. (1999) From Rhetoric to Reality: Participatory Approaches to Health Promotion with Young People, Health Education Authority

Molyneux. J. and Irvine, J. (2004) Service User and Carer Involvement in Social

133 J. of Practice Teaching \& Learning 9(2) 2009, pp.115-138. DOI: 10.1921/146066910X518139. @ w\&b 
Work Training. A Long and Winding Road? Social Work Education, 23, 3, 293-308

NHS Modernisation Agency Leadership Centre, NHS Leadership Qualities Framework NISCC (2003) The Rules for the Approval of the Degree in Social Work

NISCC (April 2006) The Standards for Practice Learning for the Degree in Social Work

Olsen R, Parker G and Drewett A (1997) 'Carers and the Missing Link: changing professional attitudes', Health and Social Care in the Community, 5, 116-23

Pithouse, P. Pfeiffer, N. and Coote, A. (1991) Is Quality Good For You? A Critical Review of Quality Assurance in Welfare Services, London, Institute of Public Policy Research

Payne, M. (1997) Modern Social Work Theory (2nd Ed) Macmillan Press Ltd

Pithouse, A. and Williamson, H. (1997) Engaging the User in Welfare Services, Venture Press

Rae, L. (2001) Training Evaluation Toolkit, Echelon Learning

Rae, L. (2002) Assessing the Value of your Training, Gower

Routledgees, S. and Wallace, A. (1982) Verdicts on Social Work, London Edward Arnold

Reynolds, R. and Reed, J. (1999) Opening Minds: User Involvement in the Production of Learning Materials on Mental Health and Distress Social Work Education, 18, 4, 417-431

Rimmer, A. and Harwood, K. (2004) Citizen Participation in the Education and Training of Social Workers, Social Work Education, 23 3, 2004, 309-323

Rojek, C, Peacock, G. and Collins, S. (1988) Social Work and Perceived Ideas, London Routledge

Ryant, J. (1969) The Revolutionary Potential of Social Work, Social Worker 37, 3 , 151-6, cited in Payne, M. (1997)Modern social work theory (2nd ed) Macmillan Press Ltd

Seebohm Report (1968) Report of the Committee on Local Authorities and Allied Personal Social Services CMND 3703, London, HMSO

Shardlow, S. and Doel, M. (1993) Examination by Triangulation: A Model for Practice Teaching, Social Work Education, 12, 3, 67-79

Shenan, G. (1998) Are we asking the Experts? Practice Teachers' use of Clients Views in Assessing Competence, Social Work Education, 17, 4, 67-79

Simpson, A. (1999) 'Creating Alliances' The Views of Users and Cares on the Education and Training Needs of Community Mental Health Nurses, Journal of Psychiatry and Mental Health Nursing, 6, 347-356,

Social Services Inspectorate (1992) Concern for Quality: The First Annual Report of the Chief Inspector, London HMSO

Social Services Inspectorate (1993) Raising the Standard: The Second Annual Report

134 J. of Practice Teaching \& Learning 9(2) 2009, pp.115-138. DOI: 10.1921/146066910X518139. @ wE-b 
of the Chief Inspector, London HMSO cited in Pithouse A and Williamson H (1997) Engaging the User in Welfare Services, Venture Press

Soffe, J, Reed J, and Freude, N. (2004) A Survey of Clinical Psychologists' Views Regarding Service User Involvement in Mental Health Services, Journal of Mental Health, 13, 6, 583-592

Stationary Office (1998) Modernising Social Services, CM 4169

Stevenson, O. and Parsole, P. (1993) Community Care and Empowerment, London, Joseph Rowntree Foundation

Suzanne, H. (2005) Participation, Discourse and Power; A Case Study in Citizen Involvement. Critical Social Work 25, 2, 164-179

Thomas, N, (2000) Children, Family and the State: Decision Making and Child Participation, Bristol The Policy Press

Thompson, N. (2000) Understanding Social Work, Preparing for Practice, Palgrave, Basingstoke.

Thompson, N. (2001) Anti-Discriminatory Practice (London Macmillan)

TOPPS (Training Organisation for the Personal Social Services) England (2002) The National Occupational Standards for Social Work, Leeds: TOPPS

Tyler, G. (2006) Addressing Barriers to Participation: Service User Involvement in Social Work Training, Social Work Education, 25, 4, 385-392.

Waterson, J. and Morris, K. (2005) Training in Social Work: Exploring Issues of Involving Users in Teaching on Social Work Degree Programmes, Social Work Education, 24, 6, 635-675.

Weedon, C. (1987) Feminist Practice and Post Structuralism, Blackwell

Wikler, L. (1979) Consumer Involvement in the training of students, Social Casework, 60, 3, 145-149

Wright, P, Turner, C. Clay, D. and Mills, H (2004) The Participation of Children and Young People in Developing Social Care; Participation Practice Guide, SCIE

WHO (World Health Organisation) (1978) Primary Health Care, Geneva: WHO Cited in Duffy J (2008) Looking out from the Middle: User Involvement in Health and Social Care in Northern Ireland. SCIE Stakeholder Participation Report. 
Appendix one

Time line (after Duffy, 2008)

UK context Northern Ireland context

\begin{tabular}{|l|l|}
\hline $\begin{array}{l}\text { 2006 Our health, our care, our say, } \\
\text { a White Paper stipulating that people } \\
\text { should be given a 'stronger voice' and } \\
\text { become 'the major drivers of service } \\
\text { development' (DH, 2006a, p5) }\end{array}$ & $\begin{array}{l}2007 \text { Health and Social Services } \\
\text { (reform) (NI) Draft Order }\end{array}$ \\
$\begin{array}{l}\text { Articles 13 and 14 proposed a } \\
\text { statutory duty of personal and public } \\
\text { involvement (PPI) and consultation } \\
\text { on health and personal social services } \\
\text { (DHSSPSNI, 2007b) }\end{array}$ \\
\hline $\begin{array}{l}\text { 2006 Reward and recognition } \\
\text { A guide for service providers, service } \\
\text { users and carers (DHSSPSNI, 2006a) }\end{array}$ & $\begin{array}{l}2007 \text { The Priorities for Action } \\
\text { 2007-2008 emphasised the need } \\
\text { for greater service user and carer } \\
\text { involvement as advocated in the } \\
\text { Quality Standards. These priorities } \\
\text { also stated 'service users and carers } \\
\text { should be involved in developing, } \\
\text { delivering and evaluating services' } \\
\text { (DHSSPSNI, 2007c, p12) }\end{array}$ \\
\hline $\begin{array}{l}\text { 2006 National Health Service Act } \\
\text { (England) required patient forums } \\
\text { to be established in each NHS trust, } \\
\text { with a role to monitor and review } \\
\text { the range of services provided or } \\
\text { arranged by the trust (DH, 2006b) }\end{array}$ & $\begin{array}{l}\text { 2006 DHSSPSN produced The } \\
\text { Quality Standards for Health and } \\
\text { Social Care by which the boards and } \\
\text { trusts would be inspected. These } \\
\text { were hailed as 'a significant step in } \\
\text { the process of placing the needs of } \\
\text { the service user and carer, and the } \\
\text { wider public at the centre of planning, } \\
\text { delivery and review of health and } \\
\text { social care services' (DHSSPSNI, } \\
\text { 2006b, pl) }\end{array}$ \\
\hline $\begin{array}{l}\text { 2003 Building on the best choice } \\
\text { highlighted the relationship between } \\
\text { choice, service responsiveness and } \\
\text { equity (DH, 2003a) }\end{array}$ & $\begin{array}{l}\text { 2004 A Healthier Future 2005-2025 } \\
\text { had 'involving people' as a key theme } \\
\text { and advocated that 'planning and } \\
\text { delivery of services be person and } \\
\text { community centred' (DHSSPSNI, } \\
\text { 2004b, p37) }\end{array}$ \\
\hline
\end{tabular}

136 J. of Practice Teaching \& Learning 9(2) 2009, pp.115-138. DOI: 10.1921/146066910X518139. @ wEb 


\begin{tabular}{|c|c|}
\hline $\begin{array}{l}\text { 2003 Department of Health priorities } \\
\text { framework 2003-2006 highlighted } \\
\text { the priority of 'improving the overall } \\
\text { experience of patients'andemphasized } \\
\text { the need to defer to patient and public } \\
\text { as well as professional knowledge } \\
\text { (DH, 2003B, p5) } \\
\end{array}$ & $\begin{array}{l}2003 \text { Health and Personal Social } \\
\text { Services (Regulation and Quality } \\
\text { Improvement) NI Order established } \\
\text { the RQIA, and placed a legislative duty } \\
\text { of quality on all HSSBs and HSSTs for } \\
\text { all the services they provided and } \\
\text { commissioned (DHSSPSNI, 2003) }\end{array}$ \\
\hline $\begin{array}{l}2002 \text { The establishment of a } \\
\text { Commission for patient and Public } \\
\text { Involvement in Health (England) }\end{array}$ & $\begin{array}{l}2002 \text { Investing in health, working } \\
\text { with communities (DHSSPSNI) } \\
\text { The involvement of patients and } \\
\text { communities is seen as crucial to the } \\
\text { future development and success of } \\
\text { health and social care programmes } \\
\text { throughout Northern Ireland }\end{array}$ \\
\hline $\begin{array}{l}2001 \text { Section } 11 \text { of the Health and } \\
\text { Social Care Act placed a duty on all } \\
\text { NHS trusts to involve and consult } \\
\text { with patients and the public, not only } \\
\text { in decisions about treatment but also } \\
\text { in the planning and development of } \\
\text { health and social care services. }\end{array}$ & $\begin{array}{l}2001 \text { Best Practice, best care a } \\
\text { consultation paper, proposed a } \\
\text { new framework to improve quality } \\
\text { through clinical and social care } \\
\text { governance. It also paved the way } \\
\text { for the development of a statutory } \\
\text { duty of quality and an independent } \\
\text { authority for inspecting, regulating } \\
\text { and improving quality in health and } \\
\text { social care services (DHSSPSNI, } \\
\text { 2001) }\end{array}$ \\
\hline $\begin{array}{l}2001 \text { Bristol Royal Infirmary } \\
\text { Inquiry (www.bristol-inquiry.org.uk/) } \\
\text { highlighted the importance of patient } \\
\text { and public involvement in creating a } \\
\text { more open and an accountable health } \\
\text { service. }\end{array}$ & $\begin{array}{l}1998 \text { Human Rights Act introduced } \\
\text { in Northern Ireland in October } 2002 \\
\text { places legal requirements on public } \\
\text { service providers to comply with the } \\
\text { European Convention on Human } \\
\text { Rights (ECHR). Article } 6 \text { refers to } \\
\text { rights to a fair trial or the right to } \\
\text { be heard, and applies to service user } \\
\text { involvement. }\end{array}$ \\
\hline $\begin{array}{l}2001 \text { Improving Healthin Wales (www. } \\
\text { walws.nhs.uk/publications/struc- } \\
\text { consul-report-e.pdf) emphasized the } \\
\text { role of service users and communities } \\
\text { in developing health policy. }\end{array}$ & $\begin{array}{l}1998 \text { Northern Ireland Act introduces } \\
\text { through section } 75 \text { the need for all } \\
\text { public service providers to promote } \\
\text { equality of opportunity in their } \\
\text { activities. }\end{array}$ \\
\hline
\end{tabular}

137 J. of Practice Teaching \& Learning 9(2) 2009, pp.115-138. DOI: 10.1921/146066910X518139. @ w\&b 
2000 The NHS Plan began to formalise the requirements of modernisation through introduction of clinical governance, patient-centred care and services developed ' around the needs and preferences of individual patients, their families and carers' (DH, 2000, p7)

2000 Our National Health (Scotland) strategy (Scottish executive, 2000) recommended that individuals, groups and communities should be involved in establishing priorities and in service planning.

1997 New Labor's The NHS: Modern, dependable. Stated that to restore public confidence in the NHS, services needed to be more 'accountable to and shaped by' the views of the public (DH, 1997, p4)

1991 The patients and users charters established a number of patient rights around consultation and minimum standards (DH, 1991)
1989 United Nations Convention on the Rights of the Child (UNCRC) emphasized children's rights to participation in services.

1989 Children Act introduced the concept of working in partnership with children and families.

1990 The NHS and Community Care Act was the first piece of legislation that formally required local authorities to consult with service users and carers in relation to service planning (Farrell, 2004)

1991 People First identified one of the underlying principles of community care to be that 'services should respond flexibly to the needs of individuals and the relatives and friends who care for them' (DHSS, 1991, p5). 